Volume 13

\title{
The Black Freedom Movement and the Politics of the Anti- Genocide Norm in the United States, 1951 - 1967
}

Daniel E. Solomon

Georgetown University

Follow this and additional works at: https://digitalcommons.usf.edu/gsp

\section{Recommended Citation}

Solomon, Daniel E. (2019) "The Black Freedom Movement and the Politics of the Anti-Genocide Norm in the United States, 1951 - 1967," Genocide Studies and Prevention: An International Journal: Vol. 13: Iss. 1: 130-143.

DOI:

https://doi.org/10.5038/1911-9933.13.1.1609

Available at: https://digitalcommons.usf.edu/gsp/vol13/iss1/13

This Articles is brought to you for free and open access by the Open Access Journals at Digital Commons @ University of South Florida. It has been accepted for inclusion in Genocide Studies and Prevention: An International Journal by an authorized editor of Digital Commons @ University of South Florida. For more information, please contact digitalcommons@usf.edu. 
The Black Freedom Movement and the Politics of the Anti-Genocide Norm in the United States, 1951 - 1967

\section{Acknowledgements}

I thank Gerald Horne and the archival staffs of the Moorland-Spingarn Research Center at Howard University and the Schomburg Center for Research in Black Culture for their research guidance. 


\title{
The Black Freedom Movement and the Politics of the Anti-Genocide Norm in the United States, 1951 - 1967
}

\author{
Daniel E. Solomon \\ Georgetown University \\ Washington D.C., USA
}

\section{Introduction}

Historians have documented well the contentious relationship between the normative architecture of international human rights and the politics of race in the postwar United States. ${ }^{1}$ The then-nascent anti-genocide norm, as articulated in the 1948 Genocide Convention, was an essential part of this historical drama. The American segregationist lobby, together with legal groups like the American Bar Association, played an important-perhaps the important - role in the US Senate's initial failure to ratify the Convention in $1950 .{ }^{2}$ In 1951, after the ratification campaign concluded, a group of black activists coordinated by the left-wing Civil Rights Congress (CRC) petitioned the United Nations with evidence of a systematic campaign of genocidal violence by the US government against its black citizens. The report, titled We Charge Genocide: The Crime of Government against the Negro People, sought to demonstrate the US federal government's criminal responsibility for a battery of abuses against black Americans, including mass lynching, material deprivation, and disenfranchisement. According to the petitioners, these abuses, taken together, amounted to genocide. ${ }^{3}$ The petition campaign set off a public relations crisis for anti-Communist advocates of new human rights norms, including officials at the US State Department and the National Association for the Advancement of Colored People (NAACP), the country's leading civil rights organization.

In studies of We Charge Genocide, scholars of both genocide and the US black freedom movement tend to describe the petition as a failed attempt to capitalize on the new anti-genocide norm for political gain. ${ }^{4}$ Other scholars use the petition's documentation of mass violence against black Americans to illustrate the analytic limits and possibilities of the concept of genocide. ${ }^{5}$ Historical depictions of the petition, however, either exclude a broader context of black mobilization around the anti-genocide norm, or attribute subsequent mobilization to a marginal fringe. ${ }^{6}$ This tendency leaves unanswered an important question for scholars seeking to understand Raphaël Lemkin's legacy and the early genesis of the anti-genocide norm: how and why did members of the postwar US black freedom movement use the anti-genocide norm to advance their political goals, despite the spectacular failure of We Charge Genocide to elicit public and official support?

To answer this question, I analyze the political uses of the norm by black freedom activists in the United States between 1951 and 1967, when the topic of genocide returned to mainstream public debate with the beginning of Wisconsin Senator William Proxmire's campaign in favor of US ratification of the Convention. My analysis consists of four parts. First, I describe how the We Charge Genocide campaign laid a foundation for the black freedom movement's subsequent mobilization around the anti-genocide norm. Many of the post-petition uses of the anti-genocide norm were a consequence of civil rights lawyer and Communist Party leader William Patterson's individual advocacy; others, however, took root with no evidence of his direct involvement. Like the We Charge Genocide campaign, later black freedom activists embraced a framework of sustained engagement with global norms and institutions to highlight ongoing abuses against black Americans. Black

\footnotetext{
${ }^{1}$ Mary Dudziak, Cold War Civil Rights (Princeton: Princeton University Press, 2000).

${ }^{2}$ Lawrence J. LeBlanc, The United States and the Genocide Convention (Durham: Duke University Press, 1991).

${ }^{3}$ Civil Rights Congress, We Charge Genocide: The Crime of Government against the Negro People (New York: Civil Rights Congress, 1951).

${ }^{4}$ Ann Curthoys and John Docker, "Defining Genocide," in The Historiography of Genocide, ed. Dan Stone (London: Palgrave Macmillan, 2008); Carol Anderson, Eyes Off the Prize: The United Nations and the African American Struggle for Human Rights, 1944-1955 (Cambridge, UK: Cambridge University Press, 2003).

${ }^{5}$ Adam Jones, Genocide: A Comprehensive Introduction, 3rd ed. (New York: Routledge, 2016), 53.

${ }^{6}$ For example, Charles H. Martin observes that "even before the CRC officially disbanded in 1956, the Genocide Petition had faded from public consciousness," till it "experienced a brief though less successful [than the Genocide Convention] renaissance" during the 1960s. Charles H. Martin, "Internationalizing 'The American Dilemma': The Civil Rights Congress and the 1951 Genocide Petition to the United Nations," Journal of American Ethnic History 16, no. 4 (1997), 35-61.
} 
mobilization around the anti-genocide norm is an early example of the norm's global character in practice.

Second, I use public speeches and pamphlets of the US black freedom movement, and private documentation by movement activists, to demonstrate how black freedom activists made use of the anti-genocide norm. I demonstrate that influential segments of the black freedom movement continued to embrace the anti-genocide norm despite the 1951 petition's failure. During the 1960s, successive leaders of the Student Nonviolent Coordinating Committee (SNCC) used the antigenocide norm as a framing device in public remarks, petition campaigns, and global coalitionbuilding. In less explicit language, other movement leaders drew parallels between anti-black violence in the United States and the proximate memory of genocidal fascism in Hitler's Europe.

Third, I demonstrate that members of the black freedom movement used the anti-genocide norm in two main ways: to critique the US government's hypocrisy in establishing the postwar liberal international order amid ongoing mass violence against black Americans; and to express solidarity with global social movements against colonialism and Cold War-era imperialism. These critiques were a departure from Lemkin's vision of the anti-genocide norm's relationship with the postwar international order. Even before the establishment of the Genocide Convention, Lemkin viewed the anti-genocide norm as a pillar of an emerging international peacemaking regime, and saw the institutions that made up that regime as a bulwark against genocide's recurrence. Black freedom activists who embraced the norm saw an apparent conflict between the redemptive promise of those institutions and the state-directed mass violence waged by and in their member states.

Lastly, I argue that the black freedom movement's mobilization around the anti-genocide norm has important historical, historiographical, and methodological implications for genocide research. Black mobilization during the post-petition period demonstrates the divergent pathways of Lemkin's legacy. The anti-genocide norm became a subject of contention beyond the narrow constraints of the Convention and its implementing bodies, and an animating force for groups whose claims to victimhood Lemkin himself rejected. A fuller intellectual history of genocide demands more focused attention to the ways in which diverse social movements understand their experiences of mass violence in relation to global anti-genocide norms.

In this paper, I define both the anti-genocide norm and the black freedom movement in broad terms. By "anti-genocide norm," I refer to an individual or organization's explicit or implicit expressions of opposition to the past, present, or future occurrence of genocide. Implicit expressions consist of analogies between instances of violence or repression and canonical genocidal events, in particular the Nazi Holocaust. In these contexts, a writer or speaker references the canonical event to convey the extreme scale, scope, or intentionality of their adversary's violence.

By "black freedom movement," I refer to the black protest groups, non-profit organizations, and activist networks that mobilized for political, social, and economic equality during the early postwar period. As Yohuru Williams argues, the category "black freedom struggle" acknowledges the fuzziness of the chronological, organizational, and ideological boundaries between the fight for civil rights and the more militant, anti-integrationist black power movement. ${ }^{7}$ Activists and organizations that participated in the postwar movement disagreed about the moral and tactical value of nonviolence versus violence, objectives of integration and civil rights versus black empowerment and nationalism, and other important matters of vision, strategy, and tactics. But despite these disagreements, the hope of black freedom remained common to all.

My aim in this paper is not to evaluate the extent to which the mass violence exacted on black Americans throughout the history of the United States does or does not conform to legal or historical definitions of genocide. This paper's central premise is that the anti-genocide norm is a dynamic historical idea, rather than a set of rigid, unchanging criteria for analyzing historical and contemporary patterns of mass violence. That idea took on a life of its own once Lemkin transformed the anti-genocide norm from an academic concept, confined to the pages of Axis Rule in Occupied Europe, into a normative instrument of international criminal law and international

${ }^{7}$ Yohuru Williams, Rethinking the Black Freedom Movement (New York: Routledge, 2015). 
institutions. As black mobilization around the norm demonstrates, the social and political contexts from which the norm emerged are as important to its intellectual history as the ideas of its progenitor.

\section{The Legacy of We Charge Genocide}

The CRC was hardly the first black freedom organization to petition the United Nations for redress of US government abuses. A flurry of petition activity followed the establishment of the United Nations and its human rights bodies: in 1947, the NAACP's An Appeal to the World provoked an impassioned debate about the scope of the new UN Human Rights Commission's jurisdiction. ${ }^{8}$ With their petition, the NAACP hoped to pressure the Truman administration to make good on its postwar human rights talk amid multiple instances of mass lethal violence against black Americans. As Carol Anderson documents, NAACP leaders referred to the US government's prosecution of Nazi war criminals at Nuremberg as evidence of a double standard: "[NAACP President Walter] White complained to [NAACP board member] Eleanor Roosevelt that, 'Negro veterans...have been done to death or mutilated with savagery equalled only at Buchenwald."'”9 Neither the CRC's petition strategy nor even the scope or scale of violence that We Charge Genocide described distinguished the 1951 petition from its predecessors. Instead, it was the left-wing affiliations of Patterson, the actor and activist Paul Robeson, W.E.B. Du Bois, and other leading petition signatories that the NAACP worried would damage the credibility of the broader push for black civil rights.

The State Department's pressure campaign came at an inauspicious time for the We Charge Genocide petitioners. The anti-Communist "red scare"-championed by Wisconsin Senator Joseph McCarthy, but by no means limited to the activities of his House Un-American Activities Committee-had a chilling effect on the black freedom movement across the United States. Throughout the early 1950s, law enforcement officials and Congressional investigators targeted black activists despite scant evidence of criminal activity. ${ }^{10}$ In the We Charge Genocide case, the State Department and other US government agencies sought to make an example of the petition's lead drafters. As the petition's lead spokesman and a proud, public member of the US Communist Party with a long record of sympathy for the Soviet Union, Patterson was especially vulnerable. US authorities seized his passport upon his return to the United States. In later years, Patterson and the CRC faced new pressure from the anti-Communist Subversive Activities Control Board, leading to the CRC's dissolution and Patterson's brief imprisonment for non-compliance with the Congressional investigation. As historians have documented, the controversy and its Cold War politics dealt a heavy blow to the campaign to ratify the Convention. ${ }^{11}$

Patterson and his colleagues - especially Marxist historian Oakley Johnson-continued their anti-genocide campaign despite these obstacles. In a June 20, 1953, fundraising letter to the CRC's supporters, Patterson described the central goals of the organization's continued mobilization around the norm: "CRC is now preparing another Petition. It will be presented to the UN this year as a sequel, together with 'We Charge Genocide,' if you will help us. We believe it is necessary in the strengthening of the fight against McCarthyism, and for democracy and peace."12 The initial petition had centered on the confluence of acute violence-in particular, lynching-against black Americans, and their systematic marginalization and impoverishment as a matter of US domestic policy. In the new report, Patterson sought to expose a new facet of the US government's genocidal

\footnotetext{
${ }^{8}$ National Association for the Advancement of Colored People, An Appeal to the World! A Statement on the Denial of Human Rights to Minorities in the Case of Citizens of Negro Descent in the United States of America and an Appeal to the United Nations for Redress (New York: NAACP, 1947).

${ }^{9}$ Anderson, Eyes Off the Prize, 63.

${ }^{10}$ Gerald Horne, Black and Red: W.E.B. Du Bois and the Afro-American Response to the Cold War, 1944- 1963 (Albany: State University of New York Press, 1986).

${ }^{11}$ LeBlanc, The United States and the Genocide Convention.

12 "Fundraising letter from William Patterson to supporters of the Civil Rights Congress," June 20, 1953, William Patterson Papers (hereafter, "Patterson Papers"), Moorland Spingarn Research Center, Howard University, Box 208-17, Folder 17.
} 
violence: the mass incarceration of black Americans by the US federal prison system. Patterson viewed the widespread abuse of black prisoners, as documented by the US Federal Bureau of Prisons itself, as evidence not just of mass harm, but of a systematic policy of violence orchestrated by all levels of the US federal government.

The second petition effort never bore fruit. In 1954-1955, Patterson spent ninety days in a Connecticut jail under charges of contempt of Congress after he failed to disclose his organizational affiliations and the CRC's contributors to the SACB. ${ }^{13}$ Beyond Patterson's individual efforts, the CRC was in no financial position to support a new petition campaign; in 1956, the organization filed for bankruptcy and dissolved. In the organization's final years, Patterson continued to project the CRC as a credible champion of the anti-genocide norm despite its financial troubles. A 1955 report to the CRC's national leadership conference identifies ratification of the Genocide Convention as one of the organization's key legislative objectives:

Here it is not just necessary to defeat the additional restrictive legislation being urged by [US Attorney General] Brownell, who is making a shambles of the Constitution and the Bill of Rights he is sworn to uphold. It is necessary to take the offensive against anti-democratic legislation already on the books, and for the passage of legislation that will expand democracy...In the second category come such legislation as: ... 3. Ratification of the UN Conventions against Genocide and for Human Rights. ${ }^{14}$

Unfortunately, the segregationist opposition among southern Democrats that had doomed the initial ratification push remained an obstacle to pro-Convention advocacy. The CRC was a lonely voice of support for US ratification; even Jewish organizations that had been outspoken in support of the Convention grew quiet as the 1950s wore on.

\section{SNCC, Black Internationalism, and the Anti-Genocide Norm}

The Brown v. Board of Education decision in 1954 shifted the black freedom movement's attention in the mid-1950s towards the implementation of legal integration throughout the Jim Crow South. ${ }^{15}$ In theory, Brown made the integration of schools and other public institutions the letter of the law; in practice, integration required that groups like the NAACP and the Southern Christian Leadership Conference (SCLC) wage forceful resistance against intransigent southern segregationists. Although the force of CRC's efforts evaporated with the organization's dissolution, black Americans still found implicit relevance in the concept of genocide and opposition to it.

During the rise and consolidation of Nazi rule in Central and Eastern Europe, it was common for black newspapers to draw parallels between violence and discrimination against black Americans and the mounting threats against Jewish communities in Nazi-occupied Europe. In September 1940, for example, the New York Amsterdam News gave front-page coverage to a profile about Eugene Bullard, a black American aviator who had flown against German forces during World War I. Bullard described the Third Reich's plans for the Aryan race: "Like your Senator Bilbo" Senator Theodore Bilbo, a prominent segregationist from Mississippi-"Adolf Hitler believes that the black race, all over the world, could best serve the white race's purpose by remaining or going back to Africa."'16 These publications were also early supporters of Lemkin's own anti-genocide campaign: in a 21 September 1946 editorial, the Chicago Defender described genocide as a "muchneeded new word" that would "give America the much needed weapon with which to combat the evil of lynching." ${ }^{17}$ Comparisons between anti-black violence in the United States and the recent

\footnotetext{
${ }^{13}$ Gerald Horne, Black Revolutionary: William Patterson and the Globalization of the African American Freedom Struggle (Champaign: University of Illinois Press, 2013).

14 "Report to Civil Rights Congress National Leadership Congress," n.d., Patterson Papers, Moorland Spingarn Research Center, Howard University, Box 208-17, Folder 15.

${ }^{15}$ Manning Marable, Race, Reform, and Rebellion: The Second Reconstruction and Beyond in Black America, 1945-2006, 3rd ed. (Jackson: University Press of Mississippi, 2007).

${ }^{16}$ Carl Lawrence, “Says Nazi Boss Okays Senator Bilbo's Plan,” New York Amsterdam News, September 7, 1940.

17 "Much-Needed New Word," Chicago Defender, September 21, 1946.
} 
memory of Nazi genocide returned to the fore as local police across the United States ramped up their violent repression of black freedom protests, civil disobedience, and other forms of collective action. The front page of the 12 February 1960 Atlanta Daily World featured an interview with Rosey Pool, a Jewish Dutch resistance fighter during World War II, on the shared themes of Nazism and American racism: "Under the 'form of mass insanity' or 'anti-otherisms' which the Nazis espoused and which manifests itself in segregation, Dr. Pool warned that 'it can happen here."'18

Prominent displays of collective action during the early 1960s built on the civil disobedience campaigns that black freedom groups had spearheaded during the previous decade. Tactical innovations in black mobilization during the late 1950s led to the creation of new organizations. Official persecution of radical activists loosened as the McCarthy era of American anti-Communism subsided, although federal law enforcement continued to infiltrate and disrupt the activities of leading movement organizations. The CRC did not re-emerge, but newer organizations did that shared the group's vision for black freedom.

One such organization was SNCC, an outgrowth of the student sit-in campaigns of the late 1950s. By the middle of the decade, SNCC would become the country's largest and most prominent network of student and youth black freedom activists. SNCC and its founders, including SCLC executive secretary Ella Baker, made coherent the disparate, localized student sit-in campaigns, and aimed to give student activists tactical and strategic independence from "old-guard" black freedom groups like the NAACP and SCLC. ${ }^{19}$ From the outset, SNCC's tactics were riskier and its vision for black freedom more radical than many of its movement counterparts. As Fanon Che Wilkins observes, internationalism distinguished SNCC's politics from organizations focused exclusively on improving civil rights for black Americans. ${ }^{20}$ In the early 1960s, new intercultural exchange programs enabled students at American universities to spend time studying and traveling on the African continent, and exchange students from sub-Saharan Africa participated in SNCC chapters across the United States. ${ }^{21}$ These friendships and networks made their mark: from its early days, SNCC leaders described the black freedom movement as a node in the broader, global struggle against the systems and legacies of imperialism and colonialism..$^{22}$

Although SNCC's most prominent organizing efforts centered on the enfranchisement of black Americans in the South, the organization used its grassroots presence to draw attention to other forms of anti-black violence and repression. In the months leading up to their massive voter registration drive during the Mississippi Freedom Summer, SNCC activists seized on the anti-genocide norm to demonstrate the centrality of white supremacy to Mississippi's Jim Crow regime. In the spring of 1964, the Mississippi state legislature passed House Bill No. 180, which made it a misdemeanor to parent a second child out of wedlock. Original versions of the bill classified the act as a felony, punishable by either sterilization of both parents or up to 5 years in the state's brutal Parchman state prison. The legislation's original penalties would have represented a significant expansion of Mississippi's legal forced sterilization regime, which the state legislature authorized in $1928 .{ }^{23}$ The main official targets of Mississippi's sterilization program were mentally disabled persons, but the deceptive, involuntary sterilization of black women by doctors and medical scientists in the state attracted such notoriety that they were nicknamed "Mississippi appendectomies." ${ }^{24}$

\footnotetext{
${ }^{18}$ William A. Fowlkes, “Author Pool Notes Similarity of Nazi Oppression, Segregation," Atlanta Daily World, February 12, 1960.

${ }^{19}$ Barbara Ransby, Ella Baker and the Black Freedom Movement: A Radical Democratic Vision (Chapel Hill: University of North Carolina Press, 2003).

${ }^{20}$ Fanon Che Wilkins, “The Making of Black Internationalists: SNCC and Africa before the Launching of Black Power, 1960-1965," Journal of African American History 92, no. 4 (Fall 2007), 467-490.

${ }^{21}$ Faith S. Holsaert et al., eds., Hands on the Freedom Plow: Personal Accounts by Women in SNCC (Champaign: University of Illinois Press, 2010).

${ }^{22}$ Wilkins, The Making of Black Internationalists.

${ }^{23}$ Edward J. Larson, Sex, Race, and Science: Eugenics in the Deep South (Baltimore: Johns Hopkins University Press, 1996).

${ }^{24}$ Elaine T. May, Barren in the Promised Land: Childless Americans and the Pursuit of Happiness (Cambridge, MA: Harvard University Press, 1997), 121.
} 
SNCC released an advocacy pamphlet, Genocide in Mississippi, to protest the repressive racism of the state legislature's actions. The first page of the pamphlet juxtaposes the Genocide Convention's definition of the term with a quote from the segregated Mississippi Democratic Party's 1960 platform, in which they opposed the Convention's ratification. ${ }^{25}$ The short pamphlet accuses Mississippi's state and federal elected officials of "designing and implementing a program of genocide against the Negroes of that state." ${ }^{26}$ The original sterilization bill is the main focus of the pamphlet. SNCC cites evidence from Mississippi legislators' public statements to demonstrate that "the intent of [House Bill No. 180] is to eliminate the population of Negroes from Mississippi... either by destroying their capacity to reproduce, or by driving them from the state." 27 The pamphlet concludes by calling on President Lyndon Johnson and Attorney General Robert Kennedy to intervene against Mississippi's legislation, lest black Mississippians opt for drastic forms of resistance against potential genocide.

The Council of Federated Organizations (COFO), the umbrella coalition of groups responsible for the Freedom Summer voter registration campaign, described the bill in a Freedom Summer legislative guide as a repressive reaction to mass black mobilization in Mississippi: "Recent political organization among the Negroes makes [the Mississippi plantation class'] majority position threatening in the eyes of the Delta's white community. There is therefore good reason, as the cotton kings of the Delta conceive it, for reducing the Negro population as rapidly as possible." 28 According to the COFO guide, state legislators viewed Genocide in Mississippi as a provocation: "... supporters or the bill prepared for a second round by distributing mimeographed copies of the SNCC pamphlet...to all members of the Senate and House. Supporters felt that they could sway votes by demonstrating that SNCC opposed the bill...Supporters of the bill were successful," and the bill passed. ${ }^{29}$

In the aftermath of the Freedom Summer, SNCC's activism became more militant as southern white supremacists dug in against the Johnson administration's new civil rights reforms, black freedom protests encountered nationwide repression, and the movement's nationalist wing grew in strength. This second generation of SNCC activists saw a narrowing distinction between domestic repression and US violence abroad. In 1966, the new SNCC chair Stokely Carmichael (Kwame Ture) popularized the term "black power" to, in part, align the US black freedom movement with the global struggle for anti-colonial liberation. For activists like Carmichael, both the growing US war in Vietnam and the slow pace of black enfranchisement and integration reinforced the urgency of a global movement against US government violence. These observations were not unique to SNCC; most of the leading black freedom organizations contributed to and led large-scale protest actions against the war. ${ }^{30}$

These twin crises also broadened use of the anti-genocide norm among black freedom campaigns. In a November 6, 1965 column in the New York Amsterdam News, Congress of Racial Equality director James Farmer lamented the "slow genocide that invests the lives of black men everywhere in this nation, laws or no laws, President or no President." ${ }^{\prime 31}$ At a July 1965 press conference in Chicago, Martin Luther King, Jr. described segregation in northern cities as a form of genocidal subjugation: "'Racism is genocide, based on the ontological affirmation...that God made an [sic] creative error."' 32 King would later use a similar formulation in his famous 14 March

\footnotetext{
${ }^{25}$ Mississippi State Democratic Party, "Excerpts from the Platform and Principles (official, white-only)," adopted June 30, 1960, accessed August 31, 2018, http://www.crmvet.org/docs/msdp60.htm.

${ }^{26}$ Student Nonviolent Coordinating Committee, Genocide in Mississippi (Atlanta: Student Nonviolent Coordinating Committee, 1964), accessed August 31, 2018, http://www.crmvet.org/docs/sncc gen.pdf, 3.

${ }^{27}$ Ibid., 4.

${ }^{28}$ Council of Federated Organizations, “The Mississippi Legislature - 1964," accessed August 31, 2018, http://www. crmvet.org/docs/6406 cofo ms leg-rpt.pdf, 30.

${ }^{29}$ Ibid., 31.

${ }^{30}$ Williams, Rethinking the Black Freedom Movement.

${ }^{31}$ James Farmer, "Sounds of Surrender," New York Amsterdam News, November 6, 1965.

32 "King Shakes up Chicago: Throngs To Follow Him To City Hall," Chicago Defender, July 24, 1965.
} 
1968 speech to the Grosse Pointe Human Relations Council in Detroit, Michigan, one of his final speeches before his assassination in Memphis, Tennessee. ${ }^{33}$

In November 1966, SNCC activist Elizabeth (Betita Martinez) Sutherland wrote to William Patterson to express the organization's interest in reprinting the We Charge Genocide petition for a contemporary audience. ${ }^{34} \mathrm{~A}$ Chicana activist and former UN researcher on decolonization in subSaharan Africa, Martinez had joined the New York Friends of SNCC in the early 1960s after a brief visit to post-revolutionary Cuba, followed by the prosecution of a North Carolina NAACP leader, sparked her interest in anti-racist organizing. ${ }^{35}$ SNCC never secured the funds for the publicationPatterson reprinted We Charge Genocide in 1970, by which point the SNCC of the 1960s campaigns had virtually ceased to exist. But Martinez and Patterson continued to correspond about SNCC's interest in global black mobilization and the anti-genocide norm.

In June 1967, Martinez wrote to Patterson to notify him that SNCC had applied for observer status at the United Nations. In the letter, she enclosed an official statement that SNCC had shared with "Afro-Asian" UN missions in response to the imprisonment of SNCC voter registration activists-including Carmichael-in Prattville, Alabama. In the statement, SNCC chair H. Rap Brown condemns the detention of SNCC activists as "a part of America's Gestapo tactics to destroy SNCC and to commit genocide against black people." 36 Martinez also shared with Patterson the text of Carmichael's speech at the Spring Mobilization to End the War at Vietnam on April 15, one of the largest demonstrations in the history of the anti-Vietnam war movement. In the speech, Carmichael reminds the crowd of the moral example of the Nuremberg prosecutions. He then uses the title of the 1951 CRC petition to frame the sustained history of US violence against marginalized communities:

When we look at the America which brought slaves here once in ships named Jesus, we charge genocide. When we look at the America which seized land from Mexico and practically destroyed the American Indians - we charge genocide. When we look at all the acts of racist exploitation which this nation has committed, whether in the name of manifest destiny or anti-Communism, we charge genocide. ${ }^{37}$

\section{Contesting Lemkin: The Anti-Genocide Norm and the Postwar International Order}

From its inception, the anti-genocide norm has been a global concept in search of local resonance. International institutions established and validated the norm through the creation of the Genocide Convention, and victim groups have used the norm to attract global attention and intervention in support of their cause. For Lemkin, institutional opposition to genocide was an essential ingredient of the crime's prevention. In "Genocide as a Crime under International Law," Lemkin applauds the General Assembly's initial declaration against genocide: "By declaring genocide a crime under international law and by making it a problem of international concern, the right of intervention on behalf of minorities slated for destruction has been established." ${ }^{38}$ Even before the Convention's creation, Lemkin viewed the UN's affirmative support for the prevention of genocide as a fundamental transformation of international order, towards an expanded concept of state responsibility for the protection of minority populations. As the Nuremberg tribunals

\footnotetext{
${ }^{33}$ Martin Luther King, Jr., "The Other America," (speech, Detroit, MI, March 14, 1968), Grosse Pointe High School, accessed March 23, 2019, http://www.gphistorical.org/mlk/mlkspeech/.

34 "Letter from Elizabeth (Betita Martinez) Sutherland to William Patterson," November 10, 1966, Patterson Papers, Moorland Spingarn Research Center, Howard University, Box 208-2, Folder 4.

${ }^{35}$ Holsaert et al., Hands on the Freedom Plow.

${ }^{36}$ SNCC New York Office, "Statement to Afro-Asian Missions to the United Nations on Events in Prattville, Alabama," June 13, 1967, enclosed in Letter from Elizabeth (Betita Martinez) Sutherland to William Patterson," November 10, 1966, Patterson Papers, Moorland Spingarn Research Center, Howard University, Box 208-2, Folder 4.

${ }^{37}$ Stokely Carmichael "Speech to the Spring Mobilization to End the War in Vietnam in New York, NY," April 15, 1967, enclosed in "Letter from Elizabeth (Betita Martinez) Sutherland to William Patterson," November 10, 1966, Patterson Papers, Moorland Spingarn Research Center, Howard University, Box 208-2, Folder 4.

${ }^{38}$ Raphaël Lemkin, “Genocide as a Crime under International Law,” American Journal of International Law 41, no. 1 (1947), 150.
} 
had demonstrated, it was possible to enact this new anti-genocide norm through the force of international law. ${ }^{39}$ Lemkin was explicit about the concept's limits, however: as We Charge Genocide stoked concerns about the Convention among pro-segregation Senators, Lemkin issued multiple public statements excluding lynching and other forms of anti-black violence from the Convention's scope. ${ }^{40}$

Genocide was one of several concepts that black freedom activists used to characterize government-directed mass violence against black Americans during the postwar period. Its descriptive specificity, however, was not what distinguished Lemkin's term from "tyranny," "mass murder," or other categories of intentional, large-scale violence against specific populations. Instead, it was the perceived weight of international criminal law that set the anti-genocide norm apart from the rest. Writing in 1947 in response to Lemkin's campaign for the creation of the Convention, Chicago Defender columnist and labor leader Willard Townsend said of genocide, "the word is new but the music is old." He cast the treaty's mechanisms of redress as a boon to black efforts to secure accountability for white supremacist violence and segregation:

Genocide being an international crime, every country will be permitted to try in its own domestic courts any criminal who might be apprehended on its territory... Now the plot thickens. Will the Ku Klux Klan or any other hate- frenzied mob be guilty of genocide under the United Nations Convention for the Prevention of Genocide? Will the Rankins, Talmadges, and other white supremacists, with their genocidal ravings, be permitted to continue their violent outbursts against Negroes, Jews, and other minority groups? ${ }^{41}$

For black freedom activists and organizations, the intervention of the United Nations and broader postwar order in the cause of black freedom was in direct tension with the Cold War-era distribution of global power. These activists understood that the architects of international human rights-officials like Secretary of State and former South Carolina governor James Byrnes - also bore great responsibility for the slow march of black freedom at home. Du Bois, the NAACP's lead delegate to the 1945 San Francisco conference that precipitated the United Nations' establishment, was fervently opposed to the involvement of the southern, pro-segregation wing of the Democratic Party in the creation of postwar human rights norms and institutions. In a July 29, 1946 column in the Chicago Defender, Du Bois condemned the incongruence between his pro-segregation views and his anti-Communist democracy promotion agenda: "Neither South Carolina nor Mr. Byrnes can represent democracy before the world." ${ }^{42}$ Despite these objections, the NAACP whose leadership fired Du Bois from his post as director of special research in 1948-responded to the segregationists' role in the new United Nations with a strategy of accommodation. ${ }^{43}$ They attempted to use their domestic political leverage and favorable relationship with the Democratic Party's northern contingent to grant black Americans a say in the outcomes of UN negotiations. The accommodationist strategy yielded little in return: in the early years of the anti-genocide norm, the Democratic Party's segregationist power base served as a constant check on the Truman administration's already-limited embrace of the UN's human rights agenda. ${ }^{44}$

Much to the NAACP's frustration, the more radical activists who embraced the anti-genocide norm dismissed the organization's attempts to accommodate the influence of the pro-segregation agenda at the United Nations. For Patterson's part, he viewed the failure to ratify the Genocide

\footnotetext{
${ }^{39}$ John Q. Barrett, “Raphaël Lemkin and 'Genocide' at Nuremberg, 1945 - 1946," in The Genocide Convention Sixty Years after its Adoption, eds. Christoph J.M. Safferling and Eckart A. Conze (The Hague: TMC Asser Press, 2010), 35-54.

${ }^{40}$ Douglas Irvin-Erickson, Raphaël Lemkin and the Concept of Genocide (Philadelphia: University of Pennsylvania Press, 2017), 206.

${ }^{41}$ Willard Townsend, "The Other Side: Genocide: The Word Is New But the Music Is Old," Chicago Defender, October 25, 1947.

${ }^{42}$ W.E.B. Du Bois, “The Winds of Time," Chicago Defender, August 17, 1946.

${ }^{43}$ Anderson, Eyes Off the Prize.

${ }^{44}$ Carol Anderson, "From Hope to Disillusion: African Americans, the United Nations, and the Struggle for Human Rights, 1944-1947," Diplomatic History 20, no. 4 (1996), 557.
} 
Convention - among other key human rights instruments - as proof positive of the US government's hypocrisy in using the institutions of the postwar order to promote human rights and democracy. In an essay on the "monumental contributions of Bandung and Geneva," Patterson described the normative failures of US support for human rights:

...Within the top ranks of that ruling clique in the USA and amongst the McCarthyites and the Dixiecrats of America the hatred for peace, while no longer blatantly expressed, is to be discerned by all who closely follow the maneuverings of those American diplomats as they mouth democratic phrases but cleverly fight against the ascendancy of peace. ${ }^{45}$

In an address to the CRC that the organization published in November 1951, Patterson described the black freedom movement's mobilization around the anti-genocide norm as a step towards undermining the white-supremacist foundations of the postwar order: "When we have presented this proof [of genocide] to the opinion of the civilized world and the United Nation, we will not have ended our fight - for those who oppress us now control the activities of the United Nations." ${ }^{46}$ Later, Patterson would recall for We Charge Genocide's new audience the relationship between US imperialism, segregation, and the US interests at the heart of the United Nations' creation: "It might be well to remind the reader who takes this Petition up that the American delegation sent to San Francisco in 1945 to establish the United Nations was headed by a noted imperialist, Edward R. Stettinius who was at the time the U.S. Secretary of State, and Tom Connally, a U.S. Senator from Texas who was an infamous racist." ${ }^{47}$ For black freedom activists, the postwar order's debt to the American segregationist lobby was insurmountable. By Patterson's logic, the only way to undermine that lobby's influence was to demonstrate the hypocrisy of the entire system.

Bound up in the critique of the postwar order was the black freedom movement's internationalism. As a Communist Party member, Patterson saw the bonds between global liberation movements as an integral aspect of the black freedom struggle. The central premise of the We Charge Genocide petition was not that black-American victimhood is exceptional, but rather that genocidal violence is a ubiquitous feature of the postwar order. In his introduction to the 1970 edition, Patterson reiterated the importance of a collective anti-genocide cause: "To further expose the hypocrisy of the U.S. rulers it is historically necessary that the black nationals and freedom-loving American whites return again to the UN with the charge of genocide against black, brown, red and yellow, and a Prayer for relief." ${ }^{48}$ For Patterson, there could be no restitution for black victims of genocide without a common struggle in support of native, Puerto Rican, and Chicano/a communities, in the United States, and Vietnamese victims of US military operations abroad. ${ }^{49}$

SNCC shared Patterson's use of the anti-genocide norm in service of the international freedom struggle. The organization's early interactions with global anti-colonial and antiimperial movements redoubled under Carmichael's leadership, marked by escalating nationwide opposition to the Vietnam War. Carmichael embraced Cuban President Fidel Castro's doctrine of "tricontinentalism," which "emphasized unity across Latin America, Africa, and Asia against racism, capitalism, and in particular, western imperialism spearheaded by the United States." ${ }^{\prime 0}$ Carmichael was a controversial participant in the International War Crimes Tribunal, a Stockholm-

\footnotetext{
${ }^{45}$ William Patterson, “The Fight against Racism: The Monumental Contributions of Bandung and Geneva,"n.d., Patterson Papers, Moorland Spingarn Research Center, Howard University, Box 208-12, Folder 1.

${ }^{46}$ Civil Rights Congress, “We Demand Freedom! Two Addresses by William L. Patterson," 1951, Patterson Papers, Moorland Spingarn Research Center, Howard University, Box 208-12, Folder 3.

${ }^{47}$ William Patterson, ed., We Charge Genocide: The Historic Petition to the United Nations for Relief from a Crime of the United States Government against the Negro People (New York: International Publishers Co., Inc., 1970), x.

${ }^{48}$ Ibid.

${ }^{49}$ William Patterson, "The People in the Battle for Democracy," n.d., Patterson Papers, Moorland Spingarn Research Center, Howard University, Box 208-11, Folder 1.

${ }^{50}$ Sarah Seidman, "Tricontinental Routes of Solidarity: Stokely Carmichael in Cuba," Journal of Transnational American Studies 4, no. 2 (2012), 1-25.
} 
based global convening of public intellectuals and activists in 1967, tasked with "prepar[ing] evidence in... the pursuit of genocidal policies, such as forced labour camps, mass burials and other techniques of extermination in the South." 51 (Arthur Klinghoffer notes that Carmichael "preferred fiery rhetoric to careful deliberations over evidence" during the Tribunal's sessions, and had his vote stripped because of his non-attendance at tribunal testimonies. ${ }^{52}$ ) In March 1967, SNCC leaders traveled to Cambodia and North Vietnam to "[investigate] U.S. war crimes." ${ }^{53}$ It was in this context that SNCC established its commitment to "positive non-alignment" in the ongoing Cold War, a reference to the Non-Aligned Movement's commitment to decolonization and anti-racism. ${ }^{54}$

\section{Towards a New Intellectual History of Genocide}

The anti-genocide norm's salience for black freedom activists during the 1950s and '60s has important implications for genocide research. The first of these implications is historical. It is true that the We Charge Genocide petition and the black freedom movement's continued mobilization around the anti-genocide norm created political obstacles to Lemkin's ratification campaign. It became increasingly difficult for Lemkin to dismiss segregationist anxieties about the Convention's potential jurisdiction over anti-black violence in the United States given prominent calls for accountability from black freedom activists. In the narrow lens of Cold War politics, that such a prominent public defender of Communists' civil liberties-in the form of the CRC-led the We Charge Genocide campaign, only made more challenging the domestic politics of securing US government support for the Convention.

These obstacles to US ratification, however should not also be interpreted as obstacles to the diffusion of the anti-genocide norm. As I have demonstrated, black freedom organizations gave the anti-genocide norm a vibrant adolescence. From the CRC to SNCC, black freedom activists used the norm to critique the emerging postwar order and its institutions, and to build strong bonds with anti-colonial and anti-imperialist movements on the basis of mutual opposition to genocide and other forms of large-scale violence. As a fervent advocate for the UN system and its new regime of international criminal institutions, Lemkin hardly anticipated that black freedom activists would put the new anti-genocide norm to such use. But the black freedom movement's example demonstrates the non-linear progress of the anti-genocide norm, in particular, and of international norms, in general: once Lemkin made the word a subject of public discussion and debate, it took on many different meanings, only some of which aligned with his original intentions.

The black freedom movement's mobilization during the early postwar period points to the possibility of an intellectual history of genocide "from below." Aside from the black freedom movement, other American social movements have found rhetorical and strategic uses for the antigenocide norm since the Convention's creation. The American Indian Movement and subsequent native rights movements, for example, used and continue to use the term to describe centuries-old patterns of US government-directed violence, deprivation, and cultural destruction against native nations. ${ }^{55}$ In her collection of essays on the Chicano/a labor movement, Elizabeth Martinez linked the Chicano/a struggle to the history of US genocide against native populations: "[America's origin] myth's omissions are grotesque. It ignores three major pillars of our nationhood: genocide, enslavement and imperialist expansion." ${ }^{56}$ For disability rights activists, the rhetorical and visual

\footnotetext{
${ }^{51}$ Bertrand Russell, War Crimes in Vietnam (London: Monthly Review Press, 2011[1967]), 126-127. For a description of SNCC's participation in the Tribunal, see Courtland Cox, interview by Joseph Mosnier, Civil Rights History Project, July 8, 2011, accessed October 9, 2018, https://cdn.loc.gov/service/afc/afc2010039/afc2010039 crhp0030 cox transcript/ afc2010039 crhp0030 cox transcript.pdf.

${ }^{52}$ Arthur J. Klinghoffer and Judith A. Klinghoffer, International Citizens' Tribunals: Mobilizing Public Opinion to Advance Human Rights (New York: Palgrave Macmillan, 2002), 155.

${ }^{53}$ Letter to US from Charlie Cobb on his trip to Vietnam, March 16, 1967, accessed October 9, 2018, http://www.crmvet.org/ lets/670316 cobb vn.pdf.

${ }^{54}$ SNCC New York Office, Statement to Afro-Asian Missions.

${ }^{55}$ Jeff Benvenuto, "What Does Genocide Produce? The Semantic Field of Genocide, Cultural Genocide, and Ethnocide in Indigenous Rights Discourse," Genocide Studies and Prevention 9, no. 2 (2015), $26-40$.

${ }^{56}$ Elizabeth Martínez, De Colores Means All of Us: Latina Views for a Multi-Colored Century (London: Verso Books, 2017 [1998]), 43.
} 
imagery of Nazi violence against disabled persons appears as a common analogue for procedures of sterilization and institutionalization. ${ }^{57}$ As Martinez's involvement in both SNCC and the Chicano/a rights movement exemplifies, inter-movement collaboration and coordination are a common feature of social-movement culture in the United States. Studying the varied uses of the anti-genocide norm for different American social movements can provide rich insight into the processes by which the norm became salient in the American public discourse.

As in the case of the black freedom movement, whether these movement claims to genocide are or are not legitimate is inconsequential. In attempting to litigate their legitimacy, historians have overlooked the full intellectual history of the anti-genocide norm: that is, how it has evolved despite the narrow scope of the international legal institutions devoted to its preservation. By focusing on the ways in which these social movements have understood the concept of genocide, genocide scholars will be better able to understand Lemkin's intellectual, political, and historical legacy. And beyond the context of genocide, a greater understanding of how these social movements respond to new international norms can clarify important processes of socialization, contention, and mobilization.

I conclude my analysis in the year 1967, when William Proxmire's pro-ratification campaign gradually returned the anti-genocide norm to mainstream prominence. It is important to note, however, that the anti-genocide norm remained salient for black freedom activists after 1967. The black freedom movement's embrace of the anti-genocide norm during the 1960s, combined with a gradual increase in elite-level support for the Convention, appeared to catalyze new uses for the norm among later generations of radical black activists. The Black Panther Party, which began as a community self-defense group in Oakland in 1966, embraced the anti-genocide norm as a rhetorical cudgel against the intensification of both US government suppression of radical black activism and the war in Vietnam during the late 1960s. ${ }^{58}$ Anti-genocide slogans also became integral to the rhetorical repertoire of pan-African solidarity that emerged with the US-based movement against South African apartheid during the 1970s and '80s. And the symbolic power of the initial We Charge Genocide petition has also endured into the present: in 2014, a group of Chicago-based anti-police brutality youth activists presented an updated version of the petition to a session of the UN Committee against Torture in Geneva. ${ }^{59}$ In a fundraising video for the Geneva briefing, one activist explained the basis for renewing the We Charge Genocide campaign: "We are always unsafe, living in our skin in this country. It's a permanent condition." ${ }^{60}$

\section{Acknowledgments}

I thank Gerald Horne and the archival staffs of the Moorland-Spingarn Research Center at Howard University and the Schomburg Center for Research in Black Culture for their research guidance.

\footnotetext{
${ }^{57}$ Tom Shakespeare, "Choices and Rights: Eugenics, Genetics and Disability Equality," Disability and Society 13, no. 5 (1998), 665-681.

${ }^{58}$ For example, see the Party's "ten-point program," which compared the restitution provided to the Jews after the Holocaust to the restitution that the Party felt black Americans deserved: "We believe that this racist government has robbed us, and now we are demanding the overdue debt of forty acres and two mules. Forty acres and two mules were promised 100 years ago as restitution for slave labor and mass murder of Black people. We will accept the payment in currency which will be distributed to our many communities. The Germans are now aiding the Jews in Israel for the genocide of the Jewish people. The Germans murdered six million Jews. The American racist has taken part in the slaughter of over fifty million Black people; therefore, we feel that this is a modest demand that we make." Marxist History Archive, "The Ten-Point Program," Black Panther Party, October 15, 1966, accessed August 31, 2018, https://www.marxists.org/history/usa/workers/black-panthers/1966/10/15.htm.

59 “We Charge Genocide Sends Delegation to United Nations," We Charge Genocide, December 15, 2014, accessed August 31, 2018, http://wechargegenocide.org/summary-of-we-charge-genocide-trip-to-united-nations-committee-againsttorture/.

${ }^{60}$ We Charge Genocide, “We Charge Genocide,” YouTube video, 1:19, September 14, 2014, accessed August 31, 2018, https://www.youtube.com/watch?v=KuZrSzc9KvQ.
} 


\section{Bibliography}

Anderson, Carol. "From Hope to Disillusion: African Americans, the United Nations, and the Struggle for Human Rights, 1944-1947." Diplomatic History 20, no. 4 (1996), 531-564. https://doi.org/10.1111/j.1467-7709.1996.tb00286.x

-------. Eyes Off the Prize: The United Nations and the African American Struggle for Human Rights, 1944 - 1955. Cambridge, UK: Cambridge University Press, 2003.

Barrett, John Q. "Raphaël Lemkin and 'Genocide' at Nuremberg, 1945 - 1946." In The Genocide Convention Sixty Years after its Adoption, edited by Christoff J.M. Safferling and Eckart A. Conze, 35-54. The Hague: TMC Asser Press, 2010.

Benvenuto, Jeff. "What Does Genocide Produce? The Semantic Field of Genocide, Cultural Genocide, and Ethnocide in Indigenous Rights Discourse." Genocide Studies and Prevention: An International Journal 9, no. 2 (2015), 26-40. https://doi.org/10.5038/1911-9933.9.2.1302

Carmichael, Stokely. "Speech to the Spring Mobilization to End the War in Vietnam in New York, NY," April 15, 1967. Enclosed in "Letter from Elizabeth (Betita Martinez) Sutherland to William Patterson." November 10, 1966. William Patterson Papers, Moorland Spingarn Research Center, Howard University, Washington, DC, United States of America. Box 2082, Folder 4.

Civil Rights Congress. We Charge Genocide: The Crime of Government against the Negro People. New York: Civil Rights Congress, 1951.

---------. “We Demand Freedom! Two Addresses by William L. Patterson." 1951. William Patterson Papers, Moorland Spingarn Research Center, Howard University, Washington, DC, United States of America. Box 208-12, Folder 3.

Council of Federated Organizations. "The Mississippi Legislature - 1964." Accessed August 31, 2018. http://www.crmvet.org/docs/6406 cofo ms leg-rpt.pdf.

Cox, Courtland. Interview by Joseph Mosnier. Civil Rights History Project. July 8, 2011. Accessed October 9, 2018. https://cdn.loc.gov/service/afc/afc2010039/afc2010039 crhp0030 cox transcript/afc2010039 crhp0030 cox transcript.pdf.

Curthoys, Ann and John Docker. "Defining Genocide." In The Historiography of Genocide, edited by Dan Stone, 9-41. London: Palgrave Macmillan UK, 2008. https://doi.org/10.1057/9780230297784 2

Du Bois, W.E.B. “The Winds of Time." Chicago Defender, August 17, 1946, 13.

Dudziak, Mary. Cold War Civil Rights: Race and the Image of American Democracy. Princeton: Princeton University Press, 2000.

Farmer, James. "Sounds of Surrender." New York Amsterdam News, November 6, 1965, 17.

Fowlkes, William A. "Author Pool Notes Similarity of Nazi Oppression, Segregation." Atlanta Daily World, February 12, 1960, 1.

"Fundraising letter from William Patterson to supporters of the Civil Rights Congress." June 20, 1953. William Patterson Papers, Moorland Spingarn Research Center, Howard University, Washington, DC, United States of America. Box 208-17, Folder 17.

Holsaert, Faith S., Martha Prescod, Norman Noonan, Judy Richardson, Betty Garman Robinson, Jean Smith Young, and Dorothy M. Zellner, eds. Hands on the Freedom Plow: Personal Accounts by Women in SNCC. Champaign: University of Illinois Press, 2010.

Horne, Gerald. Black and Red: W.E.B. Du Bois and the Afro-American Response to the Cold War, 194 -1963. Albany: State University of New York Press, 1986.

-------. Black Revolutionary: William Patterson and the Globalization of the African American Freedom Struggle. Champaign: University of Illinois Press, 2013.

Irvin-Erickson, Douglas. Raphaël Lemkin and the Concept of Genocide. Philadelphia: University of Pennsylvania Press, 2017. https://doi.org/10.9783/9780812293418

Jones, Adam. Genocide: A Comprehensive Introduction, 3rd ed. New York: Routledge, 2016. https://doi.org/10.4324/9781315725390

King, Jr., Martin Luther. “The Other America.” Speech, Detroit, MI, March 14, 1968. Grosse Pointe High School. Accessed October 11, 2018. http://www.gphistorical.org/mlk/mlkspeech/.

"King Shakes up Chicago: Throngs To Follow Him To City Hall." Chicago Defender, July 24, 1965, $1-2$. 
Klinghoffer, Arthur J. and Judith A. Klinghoffer. International Citizens' Tribunals: Mobilizing Public Opinion to Advance Human Rights. New York: Palgrave Macmillan, 2002. https://doi.org/10.1057/9780312299163

Larson, Edward J. Sex, Race, and Science: Eugenics in the Deep South. Baltimore: Johns Hopkins University Press, 1996.

Lawrence, Carl. "Says Nazi Boss Okays Senator Bilbo's Plan.” New York Amsterdam News, September 7, 1940, 1.

LeBlanc, Lawrence J. The United States and the Genocide Convention. Durham: Duke University Press, 1991.

Lemkin, Raphaël. "Genocide as a Crime under International Law." American Journal of International Law 41, no. 1 (1947), 145-151.

Letter to US from Charlie Cobb on his trip to Vietnam. March 16, 1967. Accessed October 9, 2018. http:// www.crmvet.org/lets/670316 cobb vn.pdf.

Marable, Manning. Race, Reform, and Rebellion: The Second Reconstruction and Beyond in Black America, 1945 - 2006, 3rd ed. Jackson: University Press of Mississippi, 2007.

Martin, Charles H. "Internationalizing 'The American Dilemma': The Civil Rights Congress and the 1951 Genocide Petition to the United Nations." Journal of American Ethnic History 16, no. 4 (1997), 35-61.

Martínez, Elizabeth. De Colores Means All of Us: Latina Views for a Multi-Colored Century. London: Verso Books, 2017 [1998].

Marxist History Archive. "The Ten-Point Program." Black Panther Party. October 15, 1966. Accessed August 31, 2018. https://www.marxists.org/history/usa/workers/blackpanthers/1966/10/15.htm.

May, Elaine T. Barren in the Promised Land:Childless Americans and the Pursuit of Happiness. Cambridge, MA: Harvard University Press, 1997.

Mississippi State Democratic Party. "Excerpts from the Platform and Principles (official, whiteonly)." Adopted June 30, 1960. Accessed August 31, 2018. http://www.crmvet.org/docs/ msdp60.htm.

“Much-Needed New Word." Chicago Defender, September 21, 1946, 14.

National Association for the Advancement of Colored People. An Appeal to the World! A Statement on the Denial of Human Rights to Minorities in the Case of Citizens of Negro Descent in the United States of America and an Appeal to the United Nations for Redress. New York: NAACP, 1947.

Patterson, William, ed. We Charge Genocide: The Historic Petition to the United Nations for Relief from a Crime of the United States Government against the Negro People. New York: International Publishers Co., Inc., 1970.

. "The Fight against Racism: The Monumental Contributions of Bandung and Geneva." n.d. William Patterson Papers, Moorland Spingarn Research Center, Howard University, Washington, DC, United States of America. Box 208-12, Folder 1.

"The People in the Battle for Democracy." n.d. William Patterson Papers, Moorland Spingarn Research Center, Howard University, Washington, DC, United States of America. Box 208-11, Folder 1.

Ransby, Barbara. Ella Baker and the Black Freedom Movement: A Radical Democratic Vision. Chapel Hill: University of North Carolina Press, 2003.

"Report to Civil Rights Congress National Leadership Congress." n.d. William Patterson Papers, Moorland Spingarn Research Center, Howard University, Washington, DC, United States of America. Box 208-17, Folder 15.

Russell, Bertrand. War Crimes in Vietnam. London: Monthly Review Press, 2011 [1967].

Seidman, Sarah. "Tricontinental Routes of Solidarity: Stokely Carmichael in Cuba." Journal of Transnational American Studies 4, no. 2 (2012), 1-25.

Shakespeare, Tom. "Choices and rights: Eugenics, Genetics and Disability Equality." Disability and Society 13, no. 5 (1998), 665-681. https://doi.org/10.1080/09687599826452

SNCC New York Office. "Statement to Afro-Asian Missions to the United Nations on Events in Prattville, Alabama." June 13, 1967. Enclosed in "Letter from Elizabeth (Betita Martinez) Sutherland to William Patterson." November 10, 1966. William Patterson Papers, Moorland 
Spingarn Research Center, Howard University, Washington, DC, United States of America. Box 208-2, Folder 4.

Townsend, Willard. "The Other Side: Genocide: The Word Is New But the Music Is Old." Chicago Defender, October 25, 1947, 5.

We Charge Genocide. "We Charge Genocide." YouTube video, 1:19. September 14, 2014. Accessed August 31, 2018. https://www.youtube.com/watch?v=KuZrSzc9KvQ.

"We Charge Genocide Sends Delegation to United Nations." We Charge Genocide, December 15, 2014. Accessed August 31, 2018. http://wechargegenocide.org/summary-of-we-chargegenocide-trip-to-united-nations-committee-against-torture/.

Wilkins, Fanon Che. "The Making of Black Internationalists: SNCC and Africa before the Launching of Black Power, 1960-1965." Journal of African American History, 92, no. 4 (Fall 2007), 467-490. https://doi.org/10.1086/JAAHv92n4p467

Williams, Yohuru. Rethinking the Black Freedom Movement. New York: Routledge, 2015. https://doi.org/10.4324/9780203431863 